\title{
Kuwanons, Promising inhibitors against the ACE-2, main protease of SARS-CoV-2 and falcipan-2 using molecular docking
}

\section{Kamlesh Kumari}

Deen Dayal Upadhyaya College, University of Delhi

\section{Durgseh Kumar}

Atma Ram Sanatan Dharma College, University of Delhi

\section{Ramappa Venkatesh Kumar}

Department of Zoology, Babasaheb Bhimrao Ambedkar University, Lucknow, UP, India

Prashant Singh ( $\sim$ psingh@arsd.du.ac.in )

Atma Ram Sanatan Dharma College, University of Delhi https://orcid.org/0000-0001-9648-2275

\section{Research Article}

Keywords: Kuwanon, docking, drug-likeness, ACE-2, main protease of SARS-CoV-2, falcipan-2

Posted Date: November 12th, 2020

DOI: https://doi.org/10.21203/rs.3.rs-104699/v1

License: (c) (i) This work is licensed under a Creative Commons Attribution 4.0 International License. Read Full License 


\section{Abstract}

In the present scenario, the COVID-19 has affected the nations throughout the world. Till date, neither a vaccine nor a potential medicine is available for the cure from SARS-CoV-2 infection. Main protease of SARS-CoV-2 is responsible for the replication and transcription. Further, this virus binds to the angiotensin converting enzyme-2 (ACE-2) so there is need to find molecule, to avoid the binding of novel virus to ACE2. It is reported that the molecules binds to falcipan-2 can help in the reduction of infection due to SARSCoV-2. Therefore, there is a need to find promising candidate against the receptors, spread COVID-19. In the present work, kuwanons are proposed to be promising candidates against the main protease of SARS-CoV-2, ACE-2 and falcipan-2. The interaction between the different kuwanons with different receptors has been studied using the binding energy. Kuwanon $\mathrm{M}$ was found to best inhibitor against the main protease of SARS-CoV-2 and ACE-2. Further, the drug-likeness properties of all the 16 kuwanons were studied. Kuwanon-M found to be best inhibitor against the ACE-2 and main protease of SARS-CoV-2 with binding energy of -165.349 and $-149.952 \mathrm{kcal} / \mathrm{mol}$ respectively while kuwanon-G found out to promising against the falcipan-2 with a binding energy of $-149.573 \mathrm{kcal} / \mathrm{mol}$.

\section{Introduction}

Since the prehistoric period, a major chunk of the world's population is well aware of the benefits of plantbased healthcare products due to their outstanding therapeutic properties. Further, the same attitude has been magnified among people to build strong immunity from plant sources. Most of the underexploited plants have become known to the world due to the profound impact of the folk medicine system and the modern research quest of many scientists. Among the underutilized plants, mulberry is considered as one of the most medicinally important plants, as it contains abundant natural compounds with proven therapeutic properties.(Kimura, Okuda et al. 1986; Liu, Li et al. 2016; Cakiroglu, Dervisoglu et al. 2020; Elbeaino, Incerti et al. 2020; Han, Song et al. 2020; Tam, Nam et al. 2020) Mulberry (Morus spp) is a perennial and multipurpose plant with high biomass production. It is mainly raised for silkworm rearing (Bombyx mori), which utilizes its leaves as their single food source to produce cocoons. Various parts of the mulberry plant have paramount significance for humans due to the presence of natural compounds such as flavonoids, polyphenols, alkaloids, terpenoids, steroids, and anthocyanins resveratrol, quercetin rutin, deoxynojirimycin (DNJ).(Nomura and Fukai 1981; Nomura, Hano et al. 2009; Akande, Falade et al. 2020; Arraki, Totoson et al. 2020; Gao, Zhang et al. 2020; Liu, Yan et al. 2020) In addition to the aforementioned bioactive phytochemicals, mulberry is also a rich source of Kuwanons.(Ramappa, Srivastava et al. 2020) Kuwanons are the natural isoprenylated flavonoids considered to be formed via an enzymatic Diels-Alder type reaction between an isoprenyl portion of an isoprenylphenol as the diene and and a, b-double bond of chalcone as the dienophile. Different types of Kuwanons have been reported from mulberry plants such as Kuwanon S, G, T, H , L (root bark), Kuwanon X (leaves), Kuwanon C (root). It has been revealed through various studies that Kuwanons exhibit a great diversity of biological activities including antiviral, antibacterial, tyrosinase inhibitory, antioxidant and anti-inflammatory activity.(Park, You et al. 2003; Jung, Kang et al. 2014; Esposito, Tintori et al. 2015; Kong, Park et al. 2015; Gao, Han et al. 
2016; Guo, Xu et al. 2016; Liu, Zhang et al. 2018) Despite their incredible pharmacological properties, Kuwanons have not been exploited significantly for human health enhancement.(Mihara, Hara et al. 1995; Gao, Han et al. 2016; Hu, Zheng et al. 2016; Koirala, Seong et al. 2018) Therefore, the current study is a systematic effort to reveal the potentiality and multifaceted uses of Kuwanons. Molecular docking is an interesting and promising approach to find the potential inhibitors against the receptors of interest in the form of binding energy.(Bassetto, De Burghgraeve et al. 2013; Dawood, Zarina et al. 2014; Burley, Berman et al. 2018; Abbad, Perera et al. 2019) The authors have used PDB ID of 1 R42 and it is a native human angiotensin converting enzyme-related carboxypeptidase. It is containing 805 amino-acids and human ACE2 has the receptor for the attack of the spike protein of SARS-CoV-2. Further, another pdb having ID of $6 \mathrm{LU7}$ is taken for the study and it is for the main protease of SARS-CoV-2. It is responsible for the infection in the respiratory system. Further, the PDB ID-2GHU is taken to study the activity against the falcipan-2. In the present work, kuwanons are explored for their potential in different biological potency against the main protease of SARS-CoV-2, angiotensin converting enzyme-2 and falcipan-2 using computational tools.

\section{Experimental}

Designing of the kuwanons All the kuwanon were drawn using chemdraw as in Figure S1.

\section{Molecular docking}

Structures of different kuwanons is drawn using Chemdraw and were optimized using gaussain 9.0 for further studies. For molecular docking, the protein data bank (PDB) files for main protease of SARS-CoV2, falcipan-2 and angiotensin converting enzyme-2 were taken from RCSB.(Goodsell, Zardecki et al. 2019) They were prepared using Chimera for the molecular docking.(Pettersen, Goddard et al. 2004) Molecular docking of the 16 kuwanons was performed against main protease of SARS-CoV-2, falcipan-2 and angiotensin converting enzyme-2 was performed using iGemdock. It is a reliable computational tool to understand the binding of the small molecules with the receptors in the form of physical parameters i.e. binding energy. (Kumari, Singh et al. 2017; Vishvakarma, Patel et al. 2017; Vishvakarma, Singh et al. 2017; Kumar, Singh et al. 2019; Vishvakarma, Shukla et al. 2019; Vishvakarma, Singh et al. 2019; Kumar, Kumari et al. 2020; Kumar, Kumari et al. 2020; Kumar, Kumari et al. 2020; Vishvakarma, Kumari et al. 2020) This binding energy is due to contribution by the hydrogen bonding, van der Waal's and electrostatic interaction between the amino-acids of the receptor and the small molecules.(Hsu, Chen et al. 2011) The visualization of the interaction was studied using Discovery Studio Visualizer.

\section{Drug-likeness}


It is very important to know the drug likeness properties of the designed kuwanons and determined through SWISADME, an online web-server. It provides several informations like LogP, and number of violation for different drug likeness system, like lipinski's rule of five, vaber's rule etc.(Lohidashan, Rajan et al. 2018)

\section{Results And Discussion}

\section{Molecular docking}

Kuwanons are explored for their potential in different biological potency against the main protease of SARS-CoV-2, angiotensin converting enzyme-2 and falcipan-2 using iGemDock.(Vishvakarma, Kumari et al. 2015; Chakravarty, Singh et al. 2016; Singh, Kumari et al. 2016; Singh, Kumari et al. 2016; Singh, Kumari et al. 2016; Singh, Kumari et al. 2016) The binding energy of the kuwanons based on docking angiotensin converting enzyme-2, falcipan-2 and main protease of SARS-CoV-2 is given in Table 1. (Kumar, Kumari et al. 2020; Kumar, Kumari et al. 2020)

Table 1 Binding energies of the kuwanons based on docking angiotensin converting enzyme-2, falcipan-2 and main protease of SARS-CoV-2 


\begin{tabular}{|llll|}
\hline C. & Binding energy with angiotensin & $\begin{array}{c}\text { Binding Energy with } \\
\text { falcipan-2 }\end{array}$ & $\begin{array}{c}\text { B.E. against main protease of } \\
\text { SARS-CoV-2 }\end{array}$ \\
\hline A & -99.3526 & -106.155 & -125.345 \\
\hline C & -109.516 & -108.908 & -105.293 \\
\hline D & -97.307 & -99.4465 & -101.394 \\
\hline E & -116.568 & -109.86 & -116.189 \\
\hline F & -118.384 & -102.792 & -107.511 \\
\hline G & -145.572 & -149.573 & -125.95 \\
\hline H & -137.865 & -134.123 & -127.33 \\
\hline J & -137.662 & -130.806 & -123.673 \\
\hline K & -143.382 & -147.87 & -140.915 \\
\hline L & -153.195 & -135.382 & -147.092 \\
\hline M & -165.349 & -131.544 & -149.952 \\
\hline Q & -145.354 & -142.868 & -135.106 \\
\hline S & -124.794 & -92.971 & -120.015 \\
\hline T & -104.934 & -106.189 & -120.533 \\
\hline X & -134.4 & -125.525 & -124.863 \\
\hline Y & -130.111 & -133.054 & -122.297 \\
\hline
\end{tabular}

Based on Table 1, it is clear that the kuwanons have the potential to inhibit the ACE-2, falcipan-2 and main protease of SARS-CoV-2. Kuwanon-M found to be best inhibitor against the ACE-2 and main protease of SARS-CoV-2 with binding energy of -165.349 and $-149.952 \mathrm{kcal} / \mathrm{mol}$ respectively while kuwanon-G found out to promising against the falcipan-2 with a binding energy of $-149.573 \mathrm{kcal} / \mathrm{mol}$. The interaction of the best four kuwanons against the ACE-2, falcipan-2 and main protease of SARS-CoV2 is given in Figure 2 . .

The designed kuwanons hydrogen bonding as well non-hydrogen bonding i.e. pi interaction with the amino-acids of the ACE-2, falcipan-2 and main protease of SARS-CoV-2 as in Figure 1. Based on Table 2, Kuwanon M showed pi interaction with the HIS378, ALA348 TRP349, SER47, MET62, SER43 with distance of $6.86,4.73,4.19 / 5.75 / 6.15,4.35,6.42,4.69 \AA$ respectively while showed hydrogen bonding with PHE40, SER44, SER43, ASN51 haiving distance of $2.90,2.94,3.65,4.87 \AA$ respectively.

Table 2 Interaction of the best four kuwanons with the ACE-2 


\begin{tabular}{|c|c|c|c|c|}
\hline \multirow{2}{*}{$\begin{array}{l}\text { C. } \\
\text { No. }\end{array}$} & \multicolumn{2}{|l|}{$\Pi$ Interactions } & \multicolumn{2}{|c|}{ H. Bond Interactions } \\
\hline & Interacted residue & Distance $(\AA)$ & $\begin{array}{l}\text { Interacted } \\
\text { residue }\end{array}$ & $\begin{array}{l}\text { Distance } \\
(\AA)\end{array}$ \\
\hline M & $\begin{array}{l}\text { HIS378, ALA348, TRP349, SER47, } \\
\text { MET62, SER43 }\end{array}$ & $\begin{array}{l}6.86,4.73 \\
4.19 / 5.75 / 6.15,4.35 \\
6.42,4.69\end{array}$ & $\begin{array}{l}\text { PHE40, } \\
\text { SER44, } \\
\text { SER43, } \\
\text { ASN51 }\end{array}$ & $\begin{array}{l}2.90,2.94 \\
3.65,4.87\end{array}$ \\
\hline L & PHE40, HIS378, GLU402, & $6.48,4.53,6.81$ & $\begin{array}{l}\text { ARG393, } \\
\text { TYR385, } \\
\text { ALA348 }\end{array}$ & $\begin{array}{l}4.56 / 3.62 \\
6.00,4.60\end{array}$ \\
\hline G & $\begin{array}{l}\text { HIS378, TYR385, ARG514, GLU402, } \\
\text { ASN394, ARG393, PHE40, HIS401, } \\
\text { ASP382, ALA348 }\end{array}$ & $\begin{array}{l}5.63,8.48,5.83,5.59 \\
4.60,4.74,5.52,5.45 \\
7.09,6.25\end{array}$ & $\begin{array}{l}\text { ALA348, } \\
\text { ASP382, } \\
\text { ASP350 }\end{array}$ & $\begin{array}{l}1.73 / 2.33 \\
4.96 \\
3.32 / 2.45\end{array}$ \\
\hline Q & $\begin{array}{l}\text { PHE40, ASP382, HIS401, HIS378, } \\
\text { ALA348, GLU402, ARG514 }\end{array}$ & $\begin{array}{l}\text { 5.98, 7.79, } \\
4.69 / 5.10 / 3.41,5.39, \\
6.29,6.59,6.96\end{array}$ & $\begin{array}{l}\text { HIS374, } \\
\text { GLU402 }\end{array}$ & $\begin{array}{l}4.99 \\
3.19 / 2.54\end{array}$ \\
\hline
\end{tabular}

\begin{tabular}{|c|c|c|c|c|c|}
\hline C. No. & ACE-2 & C.No. & Falcipan-2 & C.No. & Main protease of SARS-CoV-2 \\
\hline M & & G & & M & \\
\hline $\mathbf{L}$ & & K & & $\mathbf{L}$ & \\
\hline G & & Q & & K & \\
\hline Q & & $\mathbf{L}$ & & Q & \\
\hline
\end{tabular}

Based on Table 3, kuwanon G forms pi interaction with ASN81, LEU172, LEU84, ALA175, CYS42 with distance of $7.74,4.96,5.65,5.33,7.10 \AA$ respectively and forms hydrogen bonding with CYS80, GLY83, TRP43, CYS42, ALA175, HIE85 with distance of 4.73, 2.76, 5.91, 3.59, 3.76, 3.05/2.82/3.88 Å respectively.

Based on Table 4, Kuwanon M forms pi interaction with ALA70, LYS97, having distance of 4.34/4.45, 6.06/6.25, $6.95 \AA$ respectively and forms hydrogen binding with VAL73, ASN72, GLN69, ASN119, GLY71, SER121, MET17, ALA70 having distance of 3.58, 3.78, 4.42, 4.43, 3.34, 3.84, 5.60/4.54, $4.19 \AA$ respectively.

Table 3 Interaction of the best four kuwanons with the falcipan-2 


\begin{tabular}{|c|c|c|c|c|}
\hline \multirow{2}{*}{$\begin{array}{l}\text { C. } \\
\text { No. }\end{array}$} & \multicolumn{2}{|l|}{ П Interactions } & \multicolumn{2}{|l|}{ H. Bond Interactions } \\
\hline & Interacted residue & Distance $(\AA)$ & Interacted residue & Distance $(\AA)$ \\
\hline G & $\begin{array}{l}\text { ASN81, LEU172, } \\
\text { LEU84, ALA175, } \\
\text { CYS42 }\end{array}$ & $\begin{array}{l}7.74,4.96,5.65,5.33, \\
7.10\end{array}$ & $\begin{array}{l}\text { CYS80, GLY83, TRP43, } \\
\text { CYS42, ALA175, HIE85 }\end{array}$ & $\begin{array}{l}4.73,2.76,5.91,3.59, \\
3.76,3.05 / 2.82 / 3.88\end{array}$ \\
\hline K & $\begin{array}{l}\text { ALA175, CYS42, } \\
\text { TYR78, LEU84 }\end{array}$ & $\begin{array}{l}\text { 6.58, 7.38/6.11, } \\
4.78 / 6.24 / 3.93,3.84\end{array}$ & $\begin{array}{l}\text { LEU172, GLY83, } \\
\text { ASP234, SER149 }\end{array}$ & $6.16,3.11,3.99,3.70$ \\
\hline Q & $\begin{array}{l}\text { CYS80, CYS42, } \\
\text { ALA175, TRP45, } \\
\text { HIS174 }\end{array}$ & $\begin{array}{l}4.60 \\
6.70 / 5.33 / 5.14 / 4.94, \\
4.35,5.70,6.36\end{array}$ & $\begin{array}{l}\text { ASN81, GLN36, } \\
\text { HIS174, CYS42 }\end{array}$ & $3.08,6.25,4.11,4.24$ \\
\hline L & PHE164 & 4.35 & $\begin{array}{l}\text { ILE163, HIS197, } \\
\text { ASP165, GLU161, } \\
\text { LYS160 }\end{array}$ & $\begin{array}{l}4.13,4.67,5.39,4.91, \\
4.80\end{array}$ \\
\hline
\end{tabular}

Table 4 Interaction of the best four kuwanons with the main protease of SARS-CoV-2

\begin{tabular}{|c|c|c|c|c|}
\hline \multirow[t]{2}{*}{ C.No. } & \multicolumn{2}{|l|}{ П Interactions } & \multicolumn{2}{|l|}{ H. Bond Interactions } \\
\hline & $\begin{array}{l}\text { Interacted } \\
\text { residue }\end{array}$ & Distance $(\AA)$ & Interacted residue & Distance $(\AA)$ \\
\hline M & $\begin{array}{l}\text { ALA70, LYS97, } \\
\text { TRP31 }\end{array}$ & $\begin{array}{l}\text { 4.34/4.45, } \\
6.06 / 6.25,6.95\end{array}$ & $\begin{array}{l}\text { VAL73, ASN72, GLN69, } \\
\text { ASN119, GLY71, SER121, } \\
\text { MET17, ALA70 }\end{array}$ & $\begin{array}{l}3.58,3.78,4.42,4.43 \\
3.34,3.84,5.60 / 4.54 \\
4.19\end{array}$ \\
\hline L & $\begin{array}{l}\text { MET49, } \\
\text { HIS41, } \\
\text { GLU166 }\end{array}$ & $\begin{array}{l}7.49 / 7.34,6.78 \\
4.38\end{array}$ & $\begin{array}{l}\text { THR25, GLN189, LEU141, } \\
\text { GLU166, CYS145 }\end{array}$ & $\begin{array}{l}3.78,6.05,4.58 / 5.20 \\
4.94,4.17\end{array}$ \\
\hline K & $\begin{array}{l}\text { MET165, } \\
\text { CYS145, } \\
\text { HIS41, } \\
\text { MET49, }\end{array}$ & $\begin{array}{l}4.75,5.61 / 7.64 \\
4.10 / 6.86 \\
6.44 / 5.89\end{array}$ & $\begin{array}{l}\text { GLN189, GLU166, THR190, } \\
\text { GLN192, THR45, MET165 }\end{array}$ & $\begin{array}{l}5.80,3.54,4.90 / 4.85 \\
3.81,3.72,4.29\end{array}$ \\
\hline Q & CYS145 & 4.95 & $\begin{array}{l}\text { ASN119, GLY143, SER144, } \\
\text { HIS163, THR26 }\end{array}$ & $\begin{array}{l}4.58,3.40,3.27,5.33 \\
4.69\end{array}$ \\
\hline
\end{tabular}

\section{Drug likeness of the designed kuwanons}

$\operatorname{LogP}_{\mathrm{o} / \mathrm{w}}$ is a popular chemical descriptor and tells about the hydrophobicity or the lipophilicity of the molecules. It is an important physiochemical property in the discovery of a drug. A number of computational tools are available to determine the LogP value and it is a partion coefficient between he noctanol and the water system. Further, the skin permeability coefficient $\left(K_{\mathrm{p}}\right)$ is also important and it correlation between the molecular size the permeability. It is considered that more the negative value of 
the $\log \mathrm{K}_{\mathrm{p}}$ indicates higher the permeability of the molecule or compound for the skin. Actually, drug likeness evaluates the molecule ability to be as oral drug with the bioavailability or not. In most of the literature, the researchers have determined only the Lipinski's rule of five. But, one should not ignore other methods like Ghose (Amgen), Veber (GSK), Egan (Pharmacia) and Muegge (Bayer).

Drug likeness properties of the designed kuwanons are determined and given in Table 5. The promising candidate against the ACE-2 and main protease of SARS-CoV-2 is kuwanon-M. It has high LogP value means it is highly hydrophobic in nature and cannot be considered as oral drug. Further, the logKp is high in negative indicates not to be skin permeable. While kuwanon $\mathrm{G}$ showed best inbition against the falcipan-2 and it is less hydrophobic and more permeable than the kuwanon M. But the filtered or screened kuwanons (M/G) showed more violation in drug-likeness methods (Lipinski/ ghose/ veber/ egan.muegge) as in Table 5.

Table 5 Drug likeness properties of designed kuwanons as in Figure 1 


\begin{tabular}{|c|c|c|c|c|c|c|c|c|c|}
\hline \multirow{2}{*}{$\begin{array}{l}\text { C. } \\
\text { No. }\end{array}$} & \multirow{2}{*}{$\begin{array}{l}\text { Log } \\
\mathrm{P}_{\mathrm{o} / \mathrm{w}}\end{array}$} & \multirow{2}{*}{$\begin{array}{l}\text { TPSA } \\
\left(\AA^{2}\right)\end{array}$} & \multicolumn{5}{|c|}{ Drug likeness (no. of violations) } & \multirow{2}{*}{$\begin{array}{l}\mathrm{Gl} \\
\text { absorption }\end{array}$} & \multirow{2}{*}{$\begin{array}{l}\text { Log } K_{p} \text { (skin } \\
\text { permeation) } \\
\mathrm{cm} / \mathrm{s}\end{array}$} \\
\hline & & & Lipinski & Ghose & Veber & Egan & Muegge & & \\
\hline A & 4.29 & 100.13 & 0 & 0 & 0 & 0 & 1 & High & -4.95 \\
\hline C & 4.54 & 111.13 & 0 & 0 & 0 & 0 & 1 & Low & -4.50 \\
\hline D & 3.54 & 96.22 & 0 & 0 & 0 & 0 & 0 & High & -5.75 \\
\hline E & 4.41 & 107.22 & 0 & 0 & 0 & 0 & 1 & High & -4.66 \\
\hline $\mathrm{F}$ & 4.16 & 96.22 & 0 & 0 & 0 & 0 & 1 & High & -5.14 \\
\hline G & 5.17 & 209.12 & 3 & 4 & 1 & 2 & 5 & Low & -5.34 \\
\hline $\mathrm{H}$ & 6.36 & 209.12 & 3 & 4 & 1 & 2 & 5 & Low & -4.39 \\
\hline I & 5.42 & 195.18 & 2 & 4 & 1 & 2 & 4 & Low & -4.90 \\
\hline K & 5.08 & 209.12 & 3 & 4 & 1 & 2 & 5 & Low & -5.34 \\
\hline L & 3.56 & 205.12 & 3 & 3 & 1 & 1 & 5 & Low & -6.51 \\
\hline M & 7.49 & 211.26 & 3 & 4 & 1 & 2 & 6 & Low & -4.00 \\
\hline Q & 5.76 & 175.75 & 2 & 4 & 1 & 2 & 4 & Low & -4.55 \\
\hline$S$ & 4.96 & 90.90 & 0 & 1 & 0 & 0 & 1 & High & -3.95 \\
\hline $\mathrm{T}$ & 4.39 & 111.13 & 0 & 0 & 0 & 0 & 1 & Low & -4.94 \\
\hline$x$ & 4.18 & 178.91 & 2 & 4 & 1 & 2 & 3 & Low & -5.72 \\
\hline Y & 4.16 & 178.91 & 2 & 4 & 1 & 2 & 3 & Low & -5.72 \\
\hline
\end{tabular}

\section{Conclusion}

Mulberry belongs to the genus morus and considered to be a rapid growing tree. Many aspects of mulberry are explored like feeding of animal, phytochemicals used in medicine, remediation of soils etc. Kuwanon are the phytochemicals and obtained from different sources like mulberry. They have shown various biological activities like antibacterial activity against various microorganisms, anti-tuberculosis, antiviral etc. Still the mulberry is not explored thoroughly for its different application. In the present work, 16 kuwanon molecules were designed and docked against the main protease of SARS-CoV-2, ACE-2 and falcipan-2. It is found that kuwanon $M$ has shown promising role in the inhibition of the ACE-2 and main protease of SARS-CoV-2. Further, drug-likeness properties of the designed kuwanons are determined using an online web-server.

\section{Declarations}


The authors declare that they have no known competing financial interests or personal relationships that could have appeared to influence the work reported in this paper.

\section{References}

Abbad, A., R. A. P. M. Perera, et al. (2019). "Middle East respiratory syndrome coronavirus (MERS-CoV) neutralising antibodies in a high-risk human population, Morocco, November 2017 to January 2018." Eurosurveillance 24(48): 43-50.

Akande, O. A., O. O. Falade, et al. (2020). "Assessment of Mulberry Silkworm Pupae and African Palm Weevil larvae as alternative protein sources in snack fillings." Heliyon 6(4): e03754.

Arraki, K., P. Totoson, et al. (2020). "Arginase inhibitory properties of flavonoid compounds from the leaves of Mulberry (Morus alba, Moraceae)." J Pharm Pharmacol.

Bassetto, M., T. De Burghgraeve, et al. (2013). "Computer-aided identification, design and synthesis of a novel series of compounds with selective antiviral activity against chikungunya virus." Antiviral Research 98(1): $12-18$.

Burley, S. K., H. M. Berman, et al. (2018). "RCSB Protein Data Bank: Sustaining a living digital data resource that enables breakthroughs in scientific research and biomedical education." Protein Science 27(1): 316-330.

Cakiroglu, K., M. Dervisoglu, et al. (2020). "Development and characterization of black mulberry (Morus nigra) pekmez (molasses) composite films based on alginate and pectin." $\underline{\mathrm{J}}$ Texture Stud.

Chakravarty, A. K., P. Singh, et al. (2016). "One pot green synthesis of biological potent thiazolopyrans and docking against human pancreatic lipase related protein 1 receptors " Inter J Curr Adv Res 5(1): 559-563.

Dawood, S., S. Zarina, et al. (2014). "Docking studies of antidepressants against single crystal structure of tryptophan 2, 3-dioxygenase using Molegro Virtual Docker software." Pakistan Journal of Pharmaceutical Sciences 27(5): 1529-1539.

Elbeaino, T., O. Incerti, et al. (2020). "Development of an FTP-LAMP assay based on TaqMan real-time PCR and LAMP for the specific detection of Xylella fastidiosa De Donno and mulberry strains in both plants and insect vectors." J Microbiol Methods: 105992.

Esposito, F., C. Tintori, et al. (2015). "Kuwanon-L as a New Allosteric HIV-1 Integrase Inhibitor: Molecular Modeling and Biological Evaluation." Chembiochem 16(17): 2507-12.

Gao, L., J. Han, et al. (2016). "Enantioselective Total Syntheses of Kuwanon X, Kuwanon Y, and Kuwanol A." Org Lett 18(3): 360-3. 
Gao, X. H., S. D. Zhang, et al. (2020). "Anti-Inflammatory Effects of Neochlorogenic Acid Extract from Mulberry Leaf (Morus alba L.) Against LPS-Stimulated Inflammatory Response through Mediating the AMPK/Nrf2 Signaling Pathway in A549 Cells." Molecules 25(6).

Goodsell, D. S., C. Zardecki, et al. (2019). "RCSB Protein Data Bank: Enabling biomedical research and drug discovery." Protein Science.

Guo, H., Y. Xu, et al. (2016). "Kuwanon G Preserves LPS-Induced Disruption of Gut Epithelial Barrier In Vitro." Molecules 21(11).

Han, X., C. Song, et al. (2020). "Isolation and hypoglycemic effects of water extracts from mulberry leaves in Northeast China." Food Funct 11(4): 3112-3125.

Hsu, K. C., Y. F. Chen, et al. (2011). "iGEMDOCK: a graphical environment of enhancing GEMDOCK using pharmacological interactions and post-screening analysis." Bmc Bioinformatics 12.

Hu, S., Z. Zheng, et al. (2016). "The depigmenting effect of natural resorcinol type polyphenols Kuwanon 0 and Sanggenon T from the roots of morus australis." J Ethnopharmacol 195: 196-203.

Jung, H. W., S. Y. Kang, et al. (2014). "Effect of Kuwanon G isolated from the root bark of Morus alba on ovalbumin-induced allergic response in a mouse model of asthma." Phytother Res 28(11): 1713-9.

Kimura, Y., H. Okuda, et al. (1986). "Effects of phenolic constituents from the mulberry tree on arachidonate metabolism in rat platelets." J Nat Prod 49(4): 639-44.

Koirala, P., S. H. Seong, et al. (2018). "Structure(-)Activity Relationship of the Tyrosinase Inhibitors Kuwanon G, Mulberrofuran G, and Albanol B from Morus Species: A Kinetics and Molecular Docking Study." Molecules 23(6).

Kong, S. Y., M. H. Park, et al. (2015). "Kuwanon V inhibits proliferation, promotes cell survival and increases neurogenesis of neural stem cells." PLoS One 10(2): e0118188.

Kumar, D., K. Kumari, et al. (2020). "Understanding the binding affinity of noscapines with protease of SARS-CoV-2 for COVID-19 using MD simulations at different temperatures." J Biomol Struct Dyn: 1-14.

Kumar, D., K. Kumari, et al. (2020). "Selective Docking of Pyranooxazoles Against nsP2 of CHIKV Eluted Through Isothermally and Non-Isothermally MD simulations." ChemistrySelect 5(14): 4210-4220.

Kumar, D., K. Kumari, et al. (2020). "Development of a theoretical model for the inhibition of nsP3 protease of Chikungunya virus using pyranooxazoles." J Biomol Struct Dyn 30(10): 3018-3034.

Kumar, D., K. Kumari, et al. (2020). "Promising inhibitors of main protease of novel corona virus to prevent the spread of COVID-19 using docking and molecular dynamics simulation." J Biomol Struct Dyn: 1-15. 
Kumar, D., P. Singh, et al. (2019). "A Theoretical Model to Study the Interaction of Erythro-Noscapines with nsP3 protease of Chikungunya Virus " ChemistrySelect 4(17): 4892-4900.

Kumari, M., U. K. Singh, et al. (2017). "Effect of N-Butyl-N-Methyl-Morpholinium Bromide lonic Liquid on the Conformation Stability of Human Serum Albumin " ChemistrySelect 1: 1-10.

Liu, X. X., X. W. Zhang, et al. (2018). "Kuwanon $G$ attenuates atherosclerosis by upregulation of LXRalphaABCA1/ABCG1 and inhibition of NFkappaB activity in macrophages." Toxicol Appl Pharmacol 341: 56-63.

Liu, Y. G., J. L. Yan, et al. (2020). "Black mulberry ethanol extract attenuates atherosclerosis-related inflammatory factors and downregulates PPARgamma and CD36 genes in experimental atherosclerotic rats." Food Funct 11(4): 2997-3005.

Liu, Y. J., S. Y. Li, et al. (2016). "Identification and characterization of naturally occurring inhibitors against human carboxylesterase 2 in White Mulberry Root-bark." Fitoterapia 115: 57-63.

Lohidashan, K., M. Rajan, et al. (2018). "Pass and Swiss ADME collaborated in silico docking approach to the synthesis of certain pyrazoline spacer compounds for dihydrofolate reductase inhibition and antimalarial activity." Bangladesh Journal of Pharmacology. 13(1): 23-29.

Mihara, S., M. Hara, et al. (1995). "Non-peptide bombesin receptor antagonists, kuwanon G and H, isolated from mulberry." Biochem Biophys Res Commun 213(2): 594-9.

Nomura, T. and T. Fukai (1981). "Constituents of the cultivated mulberry tree." Planta Med 42(1): 79-88.

Nomura, T., Y. Hano, et al. (2009). "Chemistry and biosynthesis of isoprenylated flavonoids from Japanese mulberry tree." Proc Jpn Acad Ser B Phys Biol Sci 85(9): 391-408.

Park, K. M., J. S. You, et al. (2003). "Kuwanon G: an antibacterial agent from the root bark of Morus alba against oral pathogens." J Ethnopharmacol 84(2-3): 181-5.

Pettersen, E. F., T. D. Goddard, et al. (2004). "UCSF chimera - A visualization system for exploratory research and analysis." Journal of Computational Chemistry. 25(13): 1605-1612.

Ramappa, V. K., D. Srivastava, et al. (2020). "Mulberry 1-deoxynojirimycin (DNJ): an exemplary compound for therapeutics." The J Horticult Sci Biotech 1-8.

Singh, P., K. Kumari, et al. (2016). "Virtual Screening and Docking Studies of Synthesized Chalcones: Potent Anti-Malarial Drug " Inter J Drug Dev Res 8(1): 49-56.

Singh, P., K. Kumari, et al. (2016). "Energy Optimization And QSAR Properties Of Thiazolidine-2,4-dione And Its Analogue " J Pharm App Chem 2: 1-11.

Singh, P., K. Kumari, et al. (2016). "Green synthesis of Tetrazines and their role as human cytomegalovirus (HCMV) protease inhibitor " J Theor Comp Sci 3: 1-5. 
Singh, P., K. Kumari, et al. (2016). "Synthesis, Computational \& Docking Studies of Bis-(4Hydroxycoumarin-3-YI) Methanes As Potential Inhibitor For Carbonic Anhydrase, Glyceraldehyde-3Phosphate Dehydrogenase " J Pharm App Chem 2: 81-101.

Tam, D. N. H., N. H. Nam, et al. (2020). "Effects of Mulberry on the Central Nervous System: A Literature Review." Curr Neuropharmacol.

Vishvakarma, V. K., K. Kumari, et al. (2015). "Theoretical model to investigate the alkyl chain and anion dependent interactions of gemini surfactant with bovine serum albumin." Spectrochim Acta A Mol Biomol Spectrosc 143: 319-23.

Vishvakarma, V. K., K. Kumari, et al. (2020). "A Model To Study The Inhibition Of Arginase II With Noscapine \& Its Derivatives." J Pro Res Bioinf 2(1): 1-14.

Vishvakarma, V. K., R. Patel, et al. (2017). "Interaction between Bovine Serum Albumin and Gemini Surfactants using Molecular Docking Characterization "Inf Sci Lett 3: 1-9.

Vishvakarma, V. K., N. Shukla, et al. (2019). "A model to study the inhibition of nsP2B-nsP3 protease of dengue virus with imidazole, oxazole, triazole thiadiazole, and thiazolidine based scaffolds." Heliyon 5(8): e02124.

Vishvakarma, V. K., P. Singh, et al. (2019). "Pyrrolothiazolones as Potential Inhibitors for the nsP2B-nsP3 Protease of Dengue Virus and Their Mechanism of Synthesis " Chemistry Select 4(32): 9410-9419.

Vishvakarma, V. K., P. Singh, et al. (2017). "Rational Design of Threo as Well Erythro Noscapines, an Anticancer Drug: A Molecular Docking and Molecular Dynamic Approach "Biochemistry \& Pharmacology. 6(3): $1-7$.

\section{Figures}




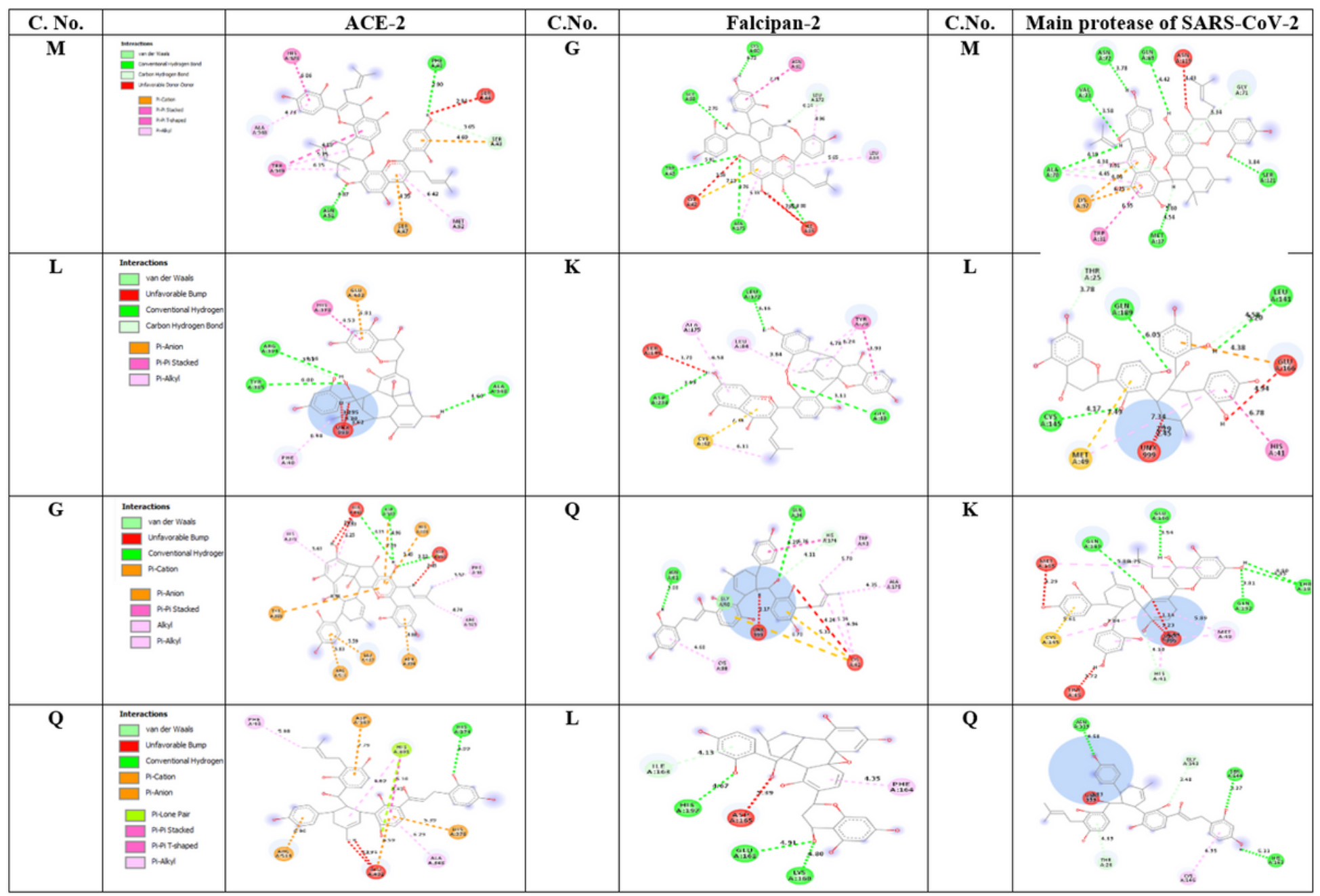

Figure 1

View for the interaction of the of the best four kuwanons with the protease of angiontensin converting enzyme-2, falcipan-2 and main protease of SARS-CoV-2 


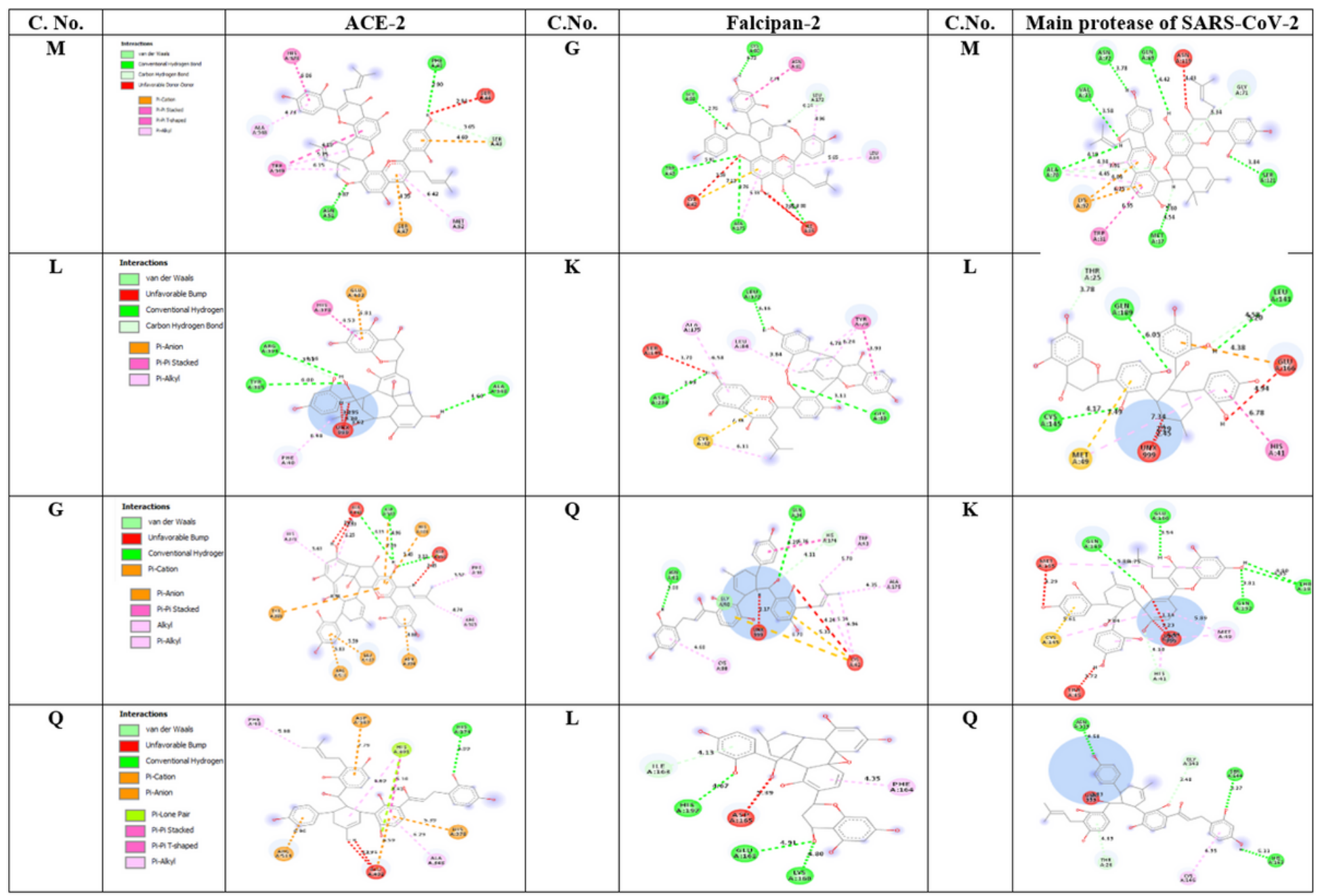

Figure 1

View for the interaction of the of the best four kuwanons with the protease of angiontensin converting enzyme-2, falcipan-2 and main protease of SARS-CoV-2

\section{Supplementary Files}

This is a list of supplementary files associated with this preprint. Click to download.

- SupportingInformation.docx

- SupportingInformation.docx 